\title{
Variation in cultured pearl quality traits in relation to position of saibo cutting on the mantle of black-lipped pearl oyster Pinctada margaritifera
}

\author{
Ky Chin-Long ${ }^{1,{ }^{*}}$, Nakasai Seiji ${ }^{2}$, Parrad Sophie ${ }^{3}$, Broustal Floriane ${ }^{1}$, Devaux Dominique ${ }^{2,4}$, Louis \\ Patricia $^{5}$
}

${ }^{1}$ Ifremer, UMR 241, EIO, Labex Corail, Centre du Pacifique, BP 49, 98719 Taravao, Tahiti, French

Polynesia

2 SCA Regahiga Pearls, BP 48, 98755 Rikitea, Gambier, French Polynesia

3 Ifremer, Station de Port en Bessin, Av. du Général de Gaulle, BP 32, 14520, Port en Bessin, France

${ }^{4}$ Groupement d'Intérêt Economique Poe O Rikitea, BP 176, 98755 Rikitea, Gambier, French Polynesia

${ }^{5}$ SCA Heimoana Poe, BP 2274, 98713 Papeete, French Polynesia

* Corresponding author : Chi-Long Ky, email address : chinky@ifremer.fr

\begin{abstract}
:
Cultured pearl production from Pinctada margaritifera uses the biomineralization capacities of the mantle graft, the saibo, which is usually obtained from only the middle mantle section of the donor oyster. To evaluate the potential for using other parts of the mantle, this study explores and describes the cultured pearl quality traits, pearl size, shape, surface defects and colour parameters obtained with saibo from the entire length of the mantle, comprising the four following sections: 1) posterior, 2) connection with the gills, 3) middle, (the section usually used commercially), and 4) anterior. Rates of nucleus retention and oyster mortality were also recorded and compared between sections. For this, two experimental grafts were designed and conducted in two contrasting culture sites, using 10 selected wild donor oysters in each to perform a total of 1536 grafts. Mantle section comparison revealed that the anterior section was different from the three other sections, showing: 1) the lowest nacre deposition rate in terms of weight and thickness, 2) the palest pearls, with lowest rate of the attractive overtone colour and the 3) a lower rate of pearls with lustre. For pearl circles and shape, no difference was recorded among the different mantle sections. Posterior, connection and middle sections showed similar pearl quality traits, revealing how the number of high quality saibo obtainable from the same batch of donors can easily be increased, thus benefitting the $P$. margaritifera pearl industry. This finding could provide significant benefits to pearl farmers and the further development of current pearl grafting practices.
\end{abstract}




\section{Highlights}

- Pearl quality traits variations were for the first time explored using all saibo position from the four mantle sections. The posterior and connection zone could be used to produce pearls with similar pearl quality traits as the middle section. The number of saibo obtainable from rare colourful wild donors could be increase.

Keywords : Pinctada margaritifera, Pearl oyster, Pearl quality traits, saibo position, Mantle tissue, Phenotype 


\section{Introduction}

Nucleated pearls are produced by species of the Pinctada genus (Southgate et al,, 2008). The cultured pearl industry is one of the largest in the Asia-Pacific region. The cultured pearls produced from the black-lipped pearl oyster P. margaritifera (Linnaeus, 1758) (Bivalvia, Pteriidae) come mostly from French Polynesia (around 90\% of world production), where pearls are the top export industry and the second largest source of income (after tourism). Other countries of the Pacific region, such as the Cook Islands, Fiji or Micronesia, have also developed pearl farming industries based on P. margaritifera (Cartier et al. 2013). Two main particularities characterize the aquaculture of $P$. margaritifera and its development in French Polynesia. First, P. margaritifera is particularly abundant in the lagoons of French Polynesia compared with other Pacific regions. Its aquaculture is based on natural spat collection from wild stock during the reproductive season, without need for any supply from hatcheries or divers/fisherman collecting adult individuals. This is not the case in other Pacific regions or, to an extent, for the exploitation of $P$. maxima (Indonesia, Myanmar) and P. fucata (Japan, China), for which the supply is hatchery-dependent. Second, the French Polynesian pearl industry is made up of hundreds of independent pearl producers (536 in 2014) spread geographically across 26 atolls and islands located in three archipelagos: $79.0 \%$ in Tuamotus, $14.5 \%$ in Gambier and 6.5\% in Society (statistics from DRMM: Direction des Ressources Marines et Minières). Consequently, great variation in cultured pearl quality trait is observed at harvest, in relation to the multiplicity of cultural practices and disparate environmental regimes.

Cultured pearl quality is defined by five visual and measurable parameters (Matlins, 2002; Taylor and Strack, 2008; Ky et al., 2013). First, the "size", which includes the diameter ( $8-20 \mathrm{~mm}$ ) and the weight of the sample, with the largest and heaviest pearls being the most 
valuable. Second, the shape, which can be round, near round, button-shaped, oval, pear to drop shape, or completely uneven/asymmetrical ("baroque"), with the perfectly round and symmetrical fetching the highest prices. P. margaritifera also produces a large number of circled pearls compared with P. fucata (Ito, 2009). Third, the colour, which has two components: the darkness level and the colour categories. The latter is a combination of bodycolor (mainly due to different pigments), and overtone (the secondary or physical colour caused by diffraction/diffusion of the light on the pearl's surface). The combination of body and secondary colours produces a large spectrum of visually perceived colours in $P$. margaritifera, from white to anthracite black, going through pink, green, blue, cream, aubergine, bronze, or a mix of nearly all of these colours that offers a rainbow effect known as peacock. Fourth, the lustre, or reflection of light from the edges of the cultured pearl, defines the shininess/glossiness of the surface. Finally, fifth, the surface quality, which is an assessment of the (often microscopic) imperfections that can mark a cultured pearl, such as signs of scratches, small holes, unevenness, abrasions, spots and roughness. It has been estimated that only 5 to 10 percent of pearls harvested can be qualified as being of top gem quality following the Tahitian regulatory control standards; these provide about $95 \%$ of farms' income (Ellis and Haws, 1999; Haws, 2002). This illustrates the great variation in pearl quality in relation to the entire production process. The key step of the graft operation is particularly important for subsequent pearl quality (Southgate and Lucas, 2008; Ky et al., 2015a).

At harvest, cultured pearl quality can be considered the result of a complex and multifactorial equation where genetics, the environment and their interactions all play key deterministic roles. Controlling quality is complex as two animals are involved; a factor that makes pearl oyster an interesting animal model for phenotype transmission and determination studies. The origin of such variations is the pearl oyster mantle, which is a metabolically and 
transcriptionally active tissue, indispensable for mollusc shell formation and growth, in which the transcriptional activity of biomineralization genes has been shown to be particularly high (Clark et al. 2010). It is these biomineralization properties that are exploited for pearl production. As mentioned above, formation of a cultured pearl requires two animals: a small piece of mantle tissue (the saibo) is dissected from a donor oyster and inserted with a round bead of nacre (a nucleus) into the gonad of a recipient oyster (Gervis and Sims, 1992; Taylor and Strack, 2008). Approximately 18 months after implantation, a pearl is harvested and $P$. margaritifera recipients are often re-implanted to produce a second pearl (surgreffe) (Demmer et al., 2016; Kishore and Southgate, 2016). Saibo donors are carefully selected based on the visible quality (colour, lustre and surface quality) of their inner shell nacre, as the mantle tissue used to make the graft will influence the quality traits of resulting pearls (Alagarswami, 1987; Taylor, 2002), including for example their colour (Wada 1985; Wada and Komaru, 1996). Suitable donors are sacrificed and both the anterior (where the byssus are located) and posterior (position of the large adductor muscle region) sections of the mantle are removed from each valve and discarded (Taylor and Strack, 2008; Kishore and Southgate, 2015). The remaining middle section is known as the "commercial" part of the mantle. It lies between the anterior and posterior sections and does not include the junction with the gills. The inner epithelial layers of mantle are then removed from the outer section of mantle tissue responsible for secreting the periostracal shell layers and are cut into square pieces for saibo . This "commercial" section is routinely and empirically used, as it corresponds to the part of the mantle that both maximizes shell growth and deposits the broadest part of the inner shell colouration band (Figure 1). Consequently, the number of useable saibo is commonly 30-40 pieces per donor oyster (both valves) in P. margaritifera of 2-3 years old (Ky et al., 2014a).

The present study focused on cultured pearl quality trait variation at the within-donor level, i.e., the variation resulting from the relative position of origin of the excised saibo on 
the mantle. Four mantle tissue sections were compared: posterior, connection zone with the gills (gills were attached to the mantle lobe), middle (commercial section) and anterior (Figure 1). For this, we performed a duplicated experimental graft (two rearing locations), using saibo cut from the four sections (both valves) of 20 wild donor oysters selected on the basis of having a common "green" phenotype basis, with a real saibo-pearl traceability. Analysis of the cultured pearl quality traits recorded should reveal any variations associated with the different mantle sections and thus the saibo positions. This study was the first designed to examine this question and will provide important information that could benefit the P. margaritifera pearl industry. 


\section{Materials and Methods}

\section{Animals}

Pinctada margaritifera var. cumingi pearl oysters, both donors and recipients, were obtained from the wild, i.e., by natural spat collection, from two distinct locations: 1) Mangareva island (Gambier archipelago, French Polynesia) and 2) Takume atolls (Tuamotu archipelago, French Polynesia). Passive techniques were employed for catching spat using commercial collectors, as described in Ky et al. (2014). After nearly one year of subsurface rearing (3-5 m below the surface), the young pearl oysters (4-5 $\mathrm{cm}$ in diameter) were then removed from the collectors on which they had developed. These juveniles were pierced and tied together onto a CTN (Cord Technical Nakasai) rearing system, where they were left until grafting. This procedure involves drilling a small hole through the base of the shell in the dorsal-posterior region, which does not affect living tissue.

Two different age groups of donor pearl oysters were used: 1) around 3 years old, with a mean $( \pm \mathrm{SE})$ dorso-ventral measurement of $112.5 \pm 9.3 \mathrm{~mm}$ in the GMR site $(\mathrm{N}=10)$, and 2) 18 months old with $55.4 \pm 9.2 \mathrm{~mm}$ in the RRR site $(\mathrm{N}=10)$. Donors were selected visually by an expert grafter for their dominant green inner shell phenotype (Figure1; Table 1). To discern the inner shell colour for this set, the grafter used a speculum to gently pry open the oyster valves (Ky et al., 2017).

Recipient pearl oysters aged almost 20 months in the Mangareva site (GMR), with mean $( \pm$ SE) dorso-ventral measurement of $76.30 \pm 0.65 \mathrm{~mm}$, were randomly selected from a set of healthy animals and taken from the CTN, detached, and stored ready to be used in the grafting procedure. Recipient pearl oysters in Raroia atoll (RRR) were also obtained from the same pool as the donors. 


\section{Experimental graft design}

The grafting procedure and culture were carried out at two commercial pearl farms operated by: 1) Regahiga Pearl farm, at Atiaoa bay, on the island of Mangareva, GMR $\left(23^{\circ} 07^{\prime}\right.$ S, 1335' W; Gambier archipelago, French Polynesia) and 2) Heimoana Poe Pearl farm, in Raroia atoll, RRR (15 $56^{\prime} \mathrm{S}, 142^{\circ} 22^{\prime} \mathrm{W}$; Tuamotu archipelago, French Polynesia).

The grafting operation was conducted by one expert in each pearl farm, as described in Ky et al (2015a). The nuclei used for this purpose were made from the shells of freshwater mussels: 1) $1.8 \mathrm{BU}$ size (equivalent to $5.45 \mathrm{~mm}$ diameter, $0.26 \mathrm{~g}$ weight; Imai Seikaku Co. Ltd., Japan) in the GMR site, and 2) $2.4 \mathrm{BU}$ size (6.054 mm diameter, $343 \mathrm{mg}$ weight Nucleus Bio, Hyakusyo Co. Japan) in RRR site. The thickness and hardness of the nacreous layers of these beads show specific gravity and thermal conductivity that make them particularly suitable for use as cultured pearl nuclei (Gervis \& Sims, 1992).

The epithelial cells required for grafting were excised from the entire mantle of the selected donor pearl oysters, including all the following sections: posterior, connection, middle and anterior (Figure 1; Table 1). A total of 801 and 735 grafts were performed in GMR and RRR, respectively. Table 1 shows the number of grafts made from each donor oyster and the number of grafts per mantle section for the two sites. All the grafted oysters were checked for nucleus retention / rejection and mortality at 45 days after the grafting operation, as described in Ky et al. (2014a). The oysters that had retained their nuclei were grown using the same rearing system in the two sites: they were drilled and fixed onto chaplets (within chaplets, oysters were attached in pairs to a rope with a monofilament fishing line). All recipient oysters were individually labelled (with a numbered plastic label) to maintain traceability between the mantle section of the saibo and the corresponding harvested pearls. Furthermore, the pearl oysters were regularly cleaned in both sites, during the same 
periods and at the same frequency, in order to remove biofouling (epibiota), which can hinder healthy oyster growth and pearl production.

Cultured pearls were harvested 20 and 15 months after grafting in the GMR and RRR sites, respectively.

\section{Pearl quality trait measurements}

The harvested pearls were cleaned by ultrasonication in soapy water (hand washing) with a LEO 801 laboratory cleaner (2-L capacity, $80 \mathrm{~W}, 46 \mathrm{kHz}$ ); they were then rinsed in distilled water. Darkness level, colour categories, surface defects, lustre, circles and shape of the cultured pearls were then evaluated visually by a single operator. All quality traits were visually classified by the naked eye (no magnification devices, such as a jeweller's loupe, were used).

Two quantitative variables were measured on the cultured pearls: 1) nacre thickness and 2) nacre weight, using a digital micrometer and a digital balance, respectively. These two components were measured as described in Ky et al (2013). Some keshi (small non-nucleated pearls formed when an oyster rejects and expulses the implanted nucleus during the culture period) were harvested, but not graded.

Visible sample surface defects including pits, bumps, scratches, deposits or other surface flaws were counted visually (without a magnifier) and each cultured pearl was then classified into one of four categories; no defects, 1 to 5 defects, 6 to 10 defects and more than 10 defects, and coded 0,1,2 or 3, respectively. Cultured pearl lustre was coded as follows: 0 , without lustre and 1, with lustre. Circled cultured pearls, characterized by regular streaks or concave rings, were not considered as having surface defects but as being of a particular cultured pearl shape (0: without circle; 1 : with circle(s)). Pearl shape was defined as round, oval or baroque (Ky et al., 2015b). 
Two kinds of colour evaluation, of the cultured pearls were made: 1) the darkness of colour, with three levels: dark, medium and pale; and 2) the visually perceived colour category, which is due to pigments (bodycolor), secondary colour (overtone) and/or a combination of the two, with seven "colour categories" detected into which all the harvested pearls could be classified: white, grey, green, yellow, peacock (a mix of red / purple and green), aubergine and blue.

\section{Statistical analysis}

All analyses were performed using $\mathrm{R} \odot$ version 3.4.0 software ( $\mathrm{R}$ foundation for Statistical Computing). The significance threshold was set at $p \leq 0.05$.

For the qualitative variables, darkness, colour, lustre, surface defects, shape and circle(s), $\chi^{2}$ tests and Fisher's exact test (when theoretical effective $<5$ ) were used to assess differences between the culture sites and among the saibo positions. When differences according to saibo position were significant, pairwise comparisons were used with Bonferroni correction to find positions that differed. Quantitative variable normality and homogeneity of variance were tested using Shapiro-Wilk and Bartlett tests, respectively. When conditions were respected t-tests were used and, if these were significant, pairwise comparisons with Bonferroni correction were applied. Otherwise, Kruskal-Wallis tests were used with quantitative variables, using post-hoc testing using Nemenyi correction when significant differences were detected. 


\section{Results}

\section{Experimental graft}

Among the total grafts performed $(\mathrm{N}=1536)$, the nucleus retention rate was $74.5 \%$ $(\mathrm{N}=1144$ ). Among the different mantle sections, the middle had a significant higher retention rate than the posterior $(78.7 \%$ vs. $66.1 \% ; p<0.001)$ (Table 2).

Between the two field sites, no significant difference $(p=0.062)$ was recorded for nucleus retention rate, with $76.5 \%(\mathrm{~N}=613)$ and $72.2 \%(\mathrm{~N}=531)$ for GMR and $\mathrm{RRR}$, respectively. In RRR, posterior position had a lesser retention rate compared with the three other positions $(56.6 \%$ vs. $76.3 \%$; $p<0.001$ ) (Table 2). In GMR, no such significant difference was detected $(p=0.239)$.

At the end of the culture period, 536 and 292 pearls were harvested in GMR and RRR, respectively.

\section{Cultured pearl nacre deposition rate in terms of weight and thickness}

In GMR, the average deposition rate for nacre was $0.033( \pm 0.015)$ g. month $^{-1}$. Between the different mantle sections, the anterior zone was significantly the least efficient, with around $-20 \%$ on average compared to the middle and posterior zones, which were not significantly different from each other (Figure 2A). For the nacre thickness, the average rate value was $6.2( \pm 2.2) \mu \mathrm{m}$. month ${ }^{-1}$. In the same way as for nacre weight, the anterior position was significantly less efficient for nacre thickness deposition, with average around $-16 \%$ in comparison to both the middle and posterior zones, which were not significantly different from each other (Figure 2C).

In RRR, the average mean nacre weight gain was $0.070( \pm 0.031)$ g.month ${ }^{-1}$. The posterior, connection and middle mantle sections were not significantly different from one another and showed significantly higher deposition rates than the anterior zone, with $+27 \%$ 
on average (Figure 2B). The same tendency was observed for the nacre thickness (average of $16.7 \pm 6.7 \mu \mathrm{m}$. month $^{-1}$ ), where the anterior position was the least efficient, showing $-22 \%$, in comparison to the three other mantle sections (Figure 2D).

Differences between the two sites were significant for the four positions $(p<0.001)$ with pearls from GMR on average 0.038 g.month ${ }^{-1}$ and $1 \mu \mathrm{m} \cdot \mathrm{month}^{-1}$ smaller. Correlations observed between nacre weight and thickness were $0.95(p<0.001)$ for GMR and 0.84 $(p<0.001)$ for RRR.

\section{Cultured pearl darkness level and colour categories}

For cultured pearl darkness level at GMR site, the anterior mantle position was found to be significantly different from the three others $(p<0.001)$, which showed similar rates (Figure 3A). Saibo from anterior section produced up to 3 times less of the darkest pearl category than the three other sections $(17.2 \%$ vs. $63.3 \%$ on average). By contrast, the anterior zone produced significantly more medium $(+40 \%)$ and up to 10 fold more pale pearls on average, than the three other sections (Figure 3A). The same tendency was observed in the RRR site, where the anterior section was significantly different from the three others and characterised by less dark (17 times) and medium (13 times) pearls and more pale pearls (9 times) (Figure 3B). Inter-site comparison revealed that GMR produced significantly more dark pearls than RRR, whatever the mantle section used as saibo, except for the connection zone, where no significant differences were found between the two sites. Inversely, the RRR site was characterised by more pale pearls, related to the high number of this class obtained with the anterior section.

Concerning cultured pearls harvested at GMR, six colour categories were observed: yellow, white, peacock, grey, green and aubergine (Figure 3C). The anterior position was significantly different from both the posterior and the middle sections $(p<0.001)$. Significantly more grey pearls $(p<0.001)$ were harvested when the anterior section had been 
used $(40.5 \%)$, rather than the middle $(18.5 \%)$ or posterior $(23.6 \%)$. By contrast, significantly more peacock pearls $(p<0.001)$ were harvested from both the middle and posterior sections, in comparison to the anterior (nearly twice as many) (Figure 3C). Pearls harvested in the RRR site, showed an additional colour category, blue, that was absent from GMR (Figure 3D). The anterior section was also significantly different from both the middle and the posterior sections with regards to colours $(p<0.001)$. In particular, the proportions of aubergine pearls for the middle (18.7\%) and posterior (33.3\%) sections were higher than for the anterior one $(7.4 \% ; p=0.016)$. The tendency was the same for green pearls, with $23.3 \%$ and $53.3 \%$ for the middle and posterior sections, respectively, while the anterior section had only $10.3 \%$ $(p<0.001)$. Peacock pearls showed the same distribution, with a proportion of $8 \%$ for the middle section and $16.7 \%$ for the posterior, compared with $1.5 \%$ for the anterior section. Finally, white pearls were the most abundant for the anterior section (45.6\%) compared with $2.7 \%$ and $6.7 \%$ in the middle $(p<0.001)$ and posterior sections $(p<0.001)$, respectively (Figure 3D). The main differences observed between the two sites were the higher proportions of peacock and green pearls harvested in GMR, while RRR was dominated by grey and green pearls. For example, peacock pearls represented only $8 \%$ in RRR, whereas they reached $45.9 \%$ in GMR. For green pearls, a significant difference $(p=0.029)$ was observed between the proportions in GMR (34.0\%) and RRR (23.3\%).

\section{Cultured pearl lustre, surface defects, circles and shapes}

The anterior position showed a significantly $(p<0.001)$ higher proportion of pearls without lustre than the three other mantle sections in both GMR $(+30 \%)$ and RRR $(+40 \%)$ sites (Figure 4A and 4B). A significant inter-site difference was only observed only for the middle section $(p=0.004)$, where RRR showed more pearls with lustre than GMR $(41.3 \%$ vs. $27 \%)$. 
Concerning pearl surface defects, in GMR, the anterior position showed the lowest rate of pearls from the first class (i.e., with 1 to 5 defects), in comparison with the three other sections $(-40 \% p<0.001)$. In RRR, there were no significant differences for defects between the four mantle sections. A difference between the sites was only found for class 1 with $55.5 \%$ in GMR and $35.6 \%$ in $\operatorname{RRR}(p=0.038)$.

No significant differences were found for cultured pearl circles or shapes among the mantle sections, whatever the site considered. 


\section{Discussion}

This study explored, for the first time, cultured pearl quality trait variation within common donor individuals along the entire mantle of $P$. margaritifera. Previous studies on the species have already been designed to examine differences in cultured pearl quality traits brought about by: 1) using different donors at the individual or family scale, originating from wild (Tayale et al., 2012) or farmed (Ky et al., 2013) stocks, or from other species of the Pinctada genus (McGinty et al, 2010), revealing evidence of family effect, even among halfsib progenies (Ky et al., 2016a); 2) rearing at different culture sites (Blay et al., 2016; Le Pabic et al., 2016), including at the archipelago scale (Ky et al., 2016b); and 3) using different cultural practices (Kishore et al., 2014; Kishore and Southgate 2016). The present study highlights intra-phenotypic pearl quality trait variations within single donor oysters, in relation to the origin position of the saibo excised from the mantle. The age of the donor used in the two culture sites (GMR and RRR) was not the same, and the culture cycle of the recipient was different. Inter-site comparison of cultured pearl quality traits could be considered as inappropriate; but this was not the case as the objective was to highlight the mantle section showing comparable potential whatever the farming process (impact of animal age, culture cycle or both of them). The experimental design was deliberately elaborate in this way; to confirm that if the anterior section gave the palest pearls, it would be the case, whatever the culture site, or the animal age used.

From the checking time to the end of the pearl oyster culture, the rate of harvested pearls in RRR site was 55.0\% (292 pearls/ 531 recipients) and in GMR 87.4\% (536 pearls/ 613 recipients). The differences of rates observed between these two sites corresponded to oysters mortalities, mainly due to predation, which pressure was more important in Tuamotu archipelago (RRR), than in Gambier archipelago (GMR) (Ky et al. 2014). 


\section{Nacre deposition rate}

Cultured pearl nacre deposition rate, assessed through nacre weight and thickness, identified the anterior section as the least productive compared with the posterior, connection and middle zones, which were not significantly different from one another. This pattern was particularly pronounced in the RRR culture site. Using these three mantle zones, nacre weight and thickness increased significantly by $+27 \%$ in RRR and $+20 \%$ in GMR on average compared with the anterior section. This inter-mantle section amplitude of variation was less than the inter-site variation, which suggests that the RRR location is the most appropriate for pearl size improvement. This was consistent with another recent study (Ky et al., 2016b), which confirmed the growth potential in favour of Tuamotu archipelago (where RRR atoll was located) compared with Gambier archipelago (where the GMR island is located). Indeed, the nacre deposition rate was faster in RRR than in GMR, because the average temperature in lagoons of Tuamotu is warmer than in the lagoon of Gambier (Ky et al., 2016b).

The results obtained, highlighting the disadvantage of using saibo from the anterior mantle section, are consistent, to a certain extent, with the shell shape of the Pinctada genus. The anterior zone of the shell is characterised by two growth-related features. First, the concentric growth lines are closer in the anterior zone than in the posterio-ventral part of the shell corresponding to the other mantle sections. This is in accordance with the fact that growth along the shell edge is not uniform and occurs initially as the projection of the long "fingers" of growth and then by the filling of the areas in between zone (Southgate and Lucas, 2008). Second, the byssus location gives an anteriorly oblique shell conformation, with specifically subtriangular anterior auricles.

\section{Cultured pearl colour}

Differences in pearl colour distribution, in terms of both darkness level and colour categories, also revealed inter-mantle section effects within each culture site. Saibo 
originating from the anterior zone produced a significantly higher proportion of pale pearls in both culture sites. Darkness level of pearls produced with saibo from the middle section was consistent with the previous difference observed between Tuamotu and Gambier archipelago (Ky et al., 2016b): more pale pearls were found in RRR culture site. In parallel, the rates of the most attractive green, peacock and aubergine pearl colours decrease significantly when using saibo from the anterior section compared to the three other zones (posterior, connection and middle). Concerning the posterior and connection sections, there is a clear potential in $P$. margaritifera to use these for saibo as they were produce an equivalent rate of overtone pearl colours in the growing conditions of the test sites in French Polynesia. In fact, near similar colour ratios were observed between these three sections within each of the culture sites.

The result obtained from the pearls also, to a certain extent, mirrored the inner shell colour profile. Indeed, when looking at the interior nacreous surface of the shell, the anterior zone corresponds to the least colourful part of the donor oyster, compared with the other three sections, which show the largest and strongest intensity of the characteristic coloured band. It is commonly known that donor tissue influences the colour of the resulting pearls (Wada 1985; Wada and Komaru 1996; Ky et al., 2017). In the present study, we demonstrate that colour transmission to the pearls is also dependent on the section of the mantle used at the scale of the individual donor.

\section{Lustre, surface defects, circles and shape}

Cultured pearl lustre had similar proportions within the culture site for the posterior, connection and middle mantle sections. Again, the anterior section was the least interesting zone to use as saibo. Significant differences existed between the culture sites, with a higher average number of pearls with lustre in RRR than in GMR. This seems to contradict previous studies (Ky et al., 2016b; Le Pabic et al., 2016), where average water temperature, recorded through the seasons, did not favour lustre. Indeed, the recent studies revealed that in 
Tuamotus archipelago (RRR site), pearl growth rate was accelerated (as observed in Fig. 2), in comparison to Gambier archipelago (GMR site), and this impacted the bright finish on pearl surface (Snow et al., 2004). This previous study reported that pearls should grow at a rate resulting in consistent regular crystal formation. A nacre deposition rate threshold may exist for a culture site, but also for the age of the donor oyster used as saibo, and age of the recipient oyster, as in the present experimental graft, where donors used in RRR site were younger than those used in the GMR site. Age influence on cultured pearl quality traits has been already examined in Ky et al., 2017c. In this last study, a duplicated graft experiment allowed the comparison of donor oyster families at 2 and 5 years old, where saibo (from middle mantle section) was inserted into recipient oysters aged 2.5 years old. The results showed: 1) an improved pearl grade, predominantly through a higher rate of 0 surface defect category, and 2) a better green / grey ratio in favour of the younger donors. Inversely, it was in the GMR site, that the lowest amount of pearls with up to 10 surface defects was observed in comparison to RRR. This result was consistent with results found by Ky et al (2016b), and suggests that surface defect determination should not be linked to nacre deposition rate, but related to a possible interaction with sexual maturity of the gonad during culture time (Ky et al., 2015a).

No difference between pearl circle and shape categories was found among pearls grown from saibo from the different sections. Indeed, pearl shape is known to be more influenced by "external" factors than donors. Such external factors include grafter skill, grafting season (Ky et al., 2015a) and system and methods of culture (Kishore and Southgate, 2016), which have an impact on recipient condition (Kishore and Southgate, 2014).

\section{Conclusions}

Our results clearly show that mantle tissue from the posterior and connection sections can be successfully used as saibo for the pearl production, as the resulting pearl quality traits 
were comparable to those produced with the middle zone in common commercial use, even for the nucleus retention rate. Indeed, by using these sections, more saibo could be obtained from the same number of donors. As the supply of pearl oysters for producers in French Polynesia has always been wild collection, finding colourful donor oysters was a prerequisite, and sometimes limiting, step before the grafting process. Frequency of colourful donor oysters revealed that such individuals are rare and dependent on the spat collection site. It is therefore crucial to find enough donor oysters to supply grafters, who need from 400 to 700 saibo per day.

To better understand and confirm the biomineralisation potential of saibo from different mantle sections, analysis of the expression of the nacreous matrix protein genes by real time PCR would be an interesting way to reveal the relative aragonite or calcite contribution of mantle from each saibo position, together with the corresponding gene expression in the pearl sac. Such molecular studies would help pearl farmers to precisely define the point where the anterior section starts.

\section{Acknowledgement}

This work was supported by grants from the Direction des Ressources Marines et Minières (TripaGEN project 2017-2019). We would especially like to thank the host sites and employees of Regahiga Pearl Farm (Mangareva island, Gambier archipelago, French Polynesia) and Heimoana Poe pearl farm (Raroia atoll, Tuamotus archipelago, French Polynesia) for their generous support. 


\section{References}

Alagarswami, K. 1987. Cultured pearls-production and quality. K. Alagarswami (Ed.), Pearl Culture, Central Marine Fisheries Research Institute, Cochin (1987), pp. 105-113

Blay, C., Parrad, S., Cabral P., Aiho V., Ky, C.L. 2016. Correlations between cultured pearl size parameters and PIF-177 biomarker expression in Pinctada margaritifera families reared in two contrasting environments. Estuar. Coast. Shelf Sci. 182, 254-260.

Cartier, E.L., Krzemnicki, M.S., Ito, M., 2013. Cultured pearl farming and production in the Federated States of Micronesia. Gems Gemnol. 48, 108-122

Demmer, J., Cabral, P., Ky, C.L., 2016. Comparison of harvested rate and nacre deposition parameters between cultured pearls issued from initial graft and second nucleus insertion in P. margaritifera . Aquac. Res. 47(10), 3297-3306.

Ellis, S., Haws, M., 1999. Producing pearls using the black-lip pearl oyster (Pinctada margaritifera). Aquafarmer Information Sheet, 141, pp. 8.

Gervis, M.H., Sims, N., 1992. The biology and culture of pearl oysters (Bivalvia: Pteriidae). Overseas Development Administration and International Center for Living Aquatic Resources Management, Manila (1992), pp. 3-38

Haws, M., 2002. The basic methods of pearl farming: a layman's manual. Center for Tropical and Subtropical Aquaculture, Hilo, pp. 5-13 
Ito, M., 2009. Improving pearl quality by grafting and husbandry methods. Aqua Tips 20,18.

Kishore, P., Hunter, J., Zeng, C., Southgate, P.C., 2014. The effects of different culture apparatuses and current velocities on byssus production by the black-lip pearl oyster, Pinctada margaritifera. Aquaculture 434, 74-77.

Kishore, P., Southgate P., 2015. Development and function of pearl-sacs grown from regenerated mantle graft tissue in the black-lip pearl oyster, Pinctada margaritifera (Linnaeus, 1758). Fish and shellfish immunol. 45, 567-573.

Kishore, P., Southgate, P., 2016. Does the quality of cultured pearls from the black-lip pearl oyster, Pinctada margaritifera, improve after the second graft? Aquaculture 446, 97 102.

Kishore, P., Southgate, P., 2016. The effect of different culture methods on the quality of round pearls produced by the black-lip pearl oyster Pinctada margaritifera (Linnaeus, 1758). Aquaculture 451, 65-71.

Ky, C.L., Blay, C., Sham Koua, M., Vanaa, V., Lo, C., Cabral, P., 2013. Family effect on cultured pearl quality in black-lipped pearl oyster Pinctada margaritifera and insights for genetic improvement. Aquat. Liv. Res. 26, 133-145. 
Ky, C.L., Molinari, N., Moe, E., Pommier, S., 2014. Impact of season and grafter skill on nucleus retention and pearl oyster mortality rate in Pinctada margaritifera aquaculture. Aquac. Inter. 22, 1689-1701.

Ky, C. L., Nakasai, S., Molinari, N., Devaux, D., 2015a. Influence of grafter skill and season on cultured pearl shape, circles and rejects in Pinctada margaritifera aquaculture in Mangareva lagoon. Aquaculture 435, 361-370.

Ky, C. L., Demmer J., Sham-Koua M., Cabral P., 2015b. Development of cultured pearl circles and shape after initial graft and second nucleus insertion in the black-lipped pearl oyster Pinctada margaritifera. Journal of Shellfish Res. 34, 319-328.

Ky, C. L., Blay, C., Lo, C. 2016a. Half-sib family effects on cultured pearl quality traits in the black-lipped pearl oyster Pinctada margaritifera: testing for indirect benefits of polyandry and polygyny. Aquac. Inter. 24, 171-182.

Ky, C. L., Okura, R., Nakasai, S., Devaux, D. 2016b. Quality Trait Signature at Archipelago Scale of the Cultured Pearls Produced by the Black-Lipped Pearl Oyster (Pinctada margaritifera var. cumingi) in French Polynesia. Journal of Shellfish Res., 35: 827-835.

Ky, C.L., Le Pabic, L., Sham Koua, M., Molinari, N., Nakasai, S., Devaux, D., 2017a. Is pearl colour produced from Pinctada margaritifera predictable through shell phenotypes and rearing environments selections? Aquac. Res. 48, 1041-1057. 
Ky, C.L., Lo, C., Planes, S., 2017b. Mono- and polychromatic inner shell phenotype diversity in Pinctada margaritifera donor pearl oysters and its relation with cultured pearl colour. Aquaculture 468, 199-205.

Ky, C. L., Demmer J., Blay C., Lo C., 2017c. Age-dependence of cultured pearl grade and colour in the black-lipped pearl oyster Pinctada margaritifera. Aquac. Res. 48(3), 955968.

Le Pabic, L., Parrad, S., Sham Koua, M., Nakasai, S., Saulnier, D., Devaux, D., Ky, C. L. 2016. Culture site dependence on pearl size realization in Pinctada margaritifera in relation to recipient oyster growth and mantle graft biomineralization gene expression using the same donor phenotype. Estuar. Coast. Shelf Sci. 182, 294-303.

Matlins, A.L., 2002. The pearl book: the definitive buying guide: how to select, buy, care for \& enjoy pearls, (3rd edition) Gemstone Press, Woodstock, VT, USA, p. 198.

McGinty, E.L., Evans, B.S., Taylor, J.U.U., Jerry, D.R., 2010. Xenografts and pearl production in two pearl oyster species, P. maxima and P. margaritifera : Effect on pearl quality and a key to understanding genetic contribution. Aquaculture 302, 175-181.

Tayale, A., Guegen, Y., Treguier, C., Le Grand, J., Cochennec-Laureau, N., Montagnani, C., Ky, C.L., 2012. Evidence of donor effect on cultured pearl quality from a duplicated grafting experiment on Pinctadamargaritifera using wild donors. Aquat. Liv. Res. 25, 269-280. 
Taylor, J.J.U., 2002. Producing golden and silver south sea pearls from Indonesian hatchery reared Pinctada maxima. World Aquaculture 2002, World Aquaculture Society, Baton Rouge LA, USA (2002), p. 754 Beijing, PR China, Apr. 23-27

Taylor, J.J., Strack, E., 2008. Pearl production. P.C. Southgate, J.S. Lucas (Eds.), The Pearl Oyster, Elsevier, Amsterdam, pp. 273-302

Snow, M.R., Pring, A., Self, P., Losic, D., Shapter, J., 2004. The origin of the color of pearl in iridescence from nano-composite structures of the nacre. Amer. Mineral. 89, 13531358.

Southgate, P.C., Lucas, J., 2008. In: Southgate PC, Lucas JS, editors. The Pearl Oyster. Amsterdam: Elsevier; pp. 544.

Southgate, P.C., Strack, E., Hart, A., Wada, K.T., Monteforte, M., Cariño, M., Langy, S., Lo, C., Acosta-Salmón, H., Wang, A., 2008. Exploitation and Culture of Major Commercial Species. In: Southgate PC, Lucas JS, editors. The Pearl Oyster. Amsterdam: Elsevier; pp. 303-355.

Wada, K.T., 1985. The pearls produced from the groups of pearl oysters selected for colour of nacre in shell for two generations. Bull. Natl. res. Aquacult. Yoshokukenho 7, 1-7.

Wada, K.T., Komaru, A., 1996. Color and weight of pearls produced by grafting the mantle tissue from a selected population for white shell color of the japanese pearl oyster Pinctada fucata martensii (dunker). Aquaculture 142, 25-32. 
Fig. 1. Donor Pinctada margaritifera with: a) two shell valves showing, on the right, the four sections of the entire dilated mantle tissue: posterior $(\mathrm{P})$, connection with the gill $(\mathrm{C})$, middle corresponding to commercial zone usually used for saibo production (M) and anterior (A), and showing the correspondence, on the left, with the zones of contact with the inner shell zone exhibiting the colourful band characteristic of donor oysters; and b) one shell valve removed showing the entire contracted mantle, revealing the corresponding contact zone with the colourful inner shell and highlighting the narrowing of the coloured band adjacent to the anterior section. The dotted lines indicate the areas of mantle tissue excised for saibo production from the four sections A, M, C and P. General anatomy: am, adductor muscle; gi, gills; by, byssus; cn, coloured nacreous zone.

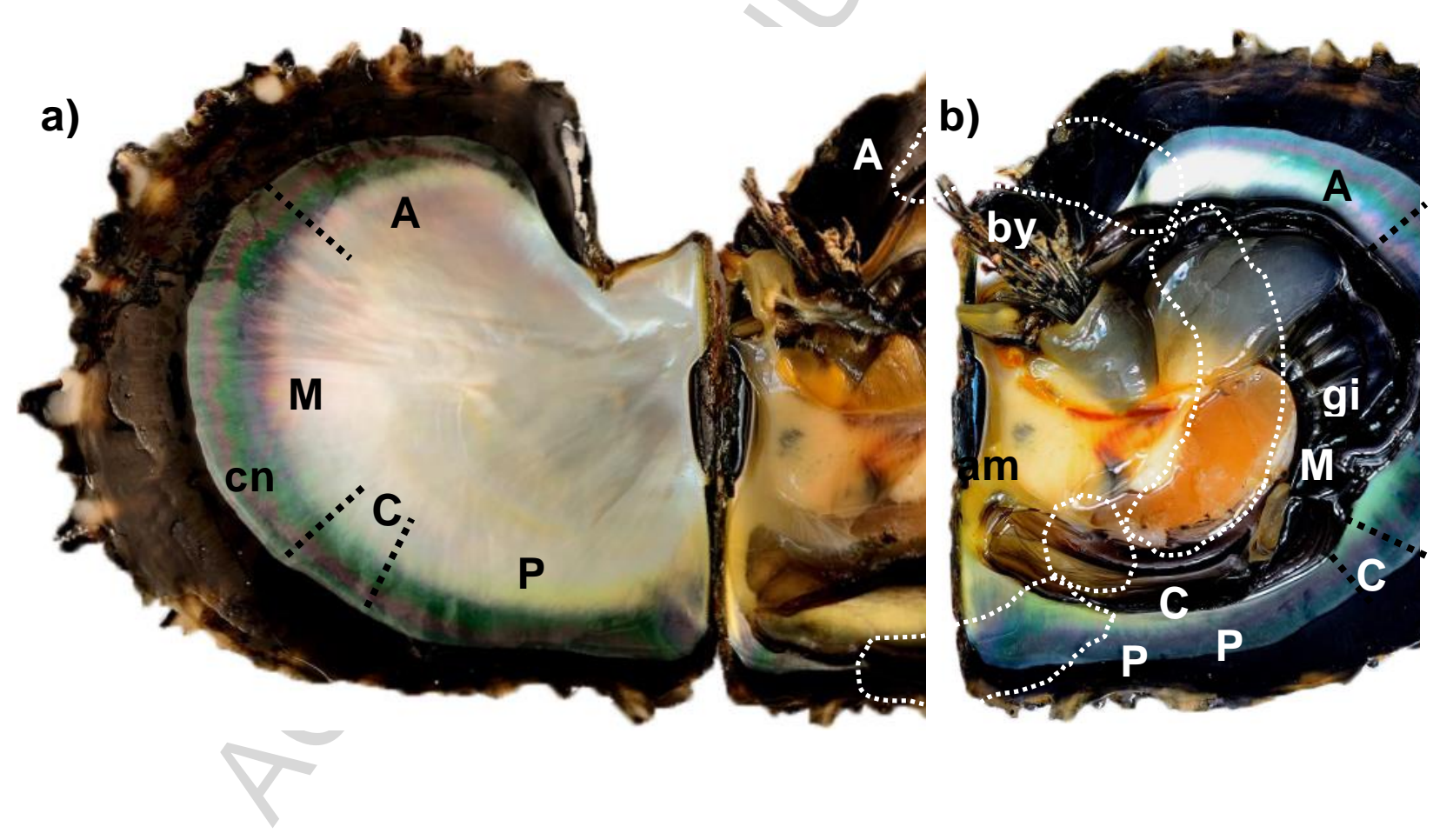


Fig. 2. Cultured pearl nacre deposition rate, expressed in weight (g.) and in thickness (mm) per month of culture, in Pinctada margaritifera reared on the two commercial pearl farms on Mangareva island (GMR, parts A and C) and Raroia atoll (RRR, parts B and D). The data that were significantly different at $p<0.05$ between the mantle sections are indicated with letters.

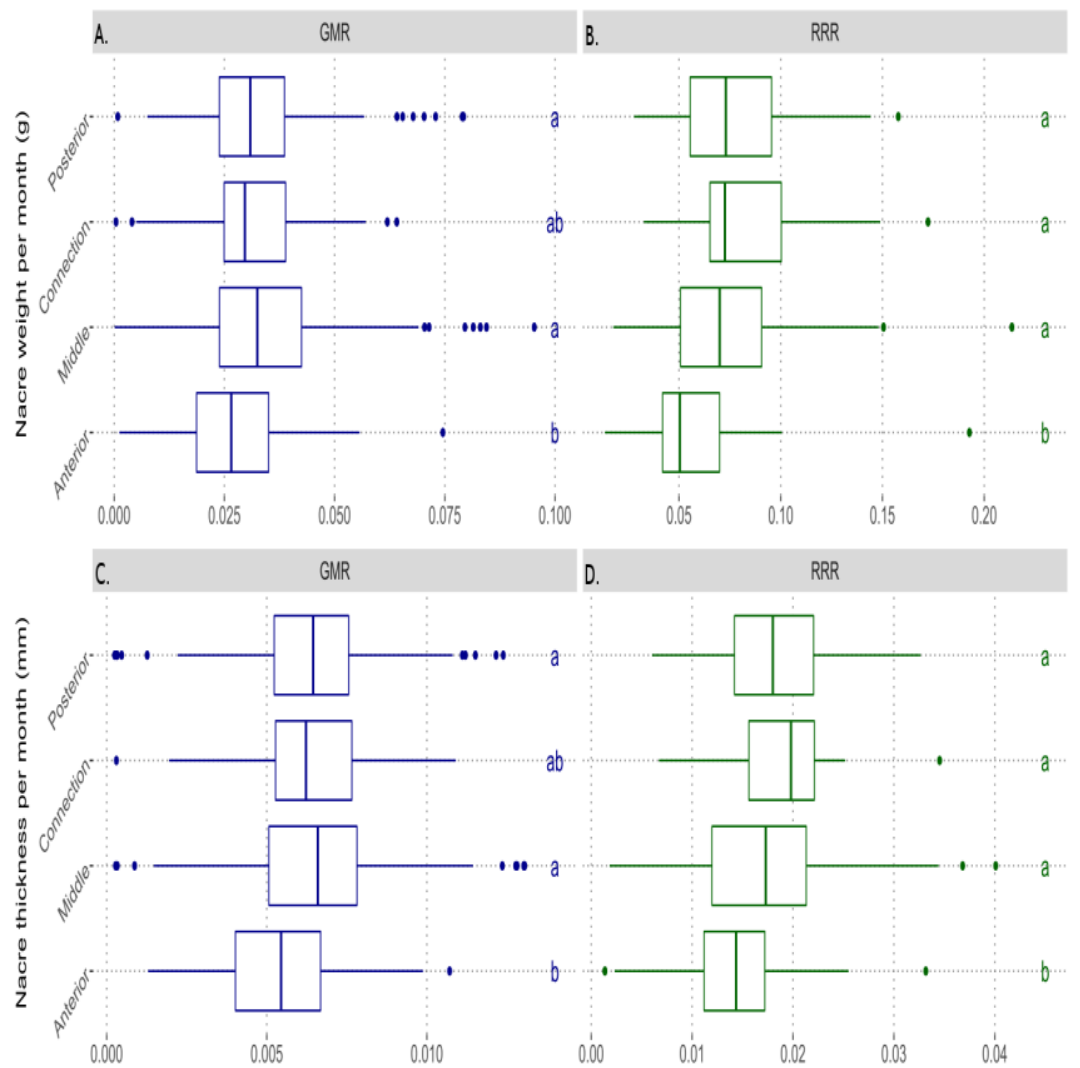


Fig. 3. Cultured pearl darkness level and colour categories in Pinctada margaritifera harvested at the two commercial culture sites on Mangareva island (GMR, parts A and C) and Raroia atoll (RRR, parts B and D). The data that were significantly different at $p<0.05$ between the mantle sections are indicated with letters.

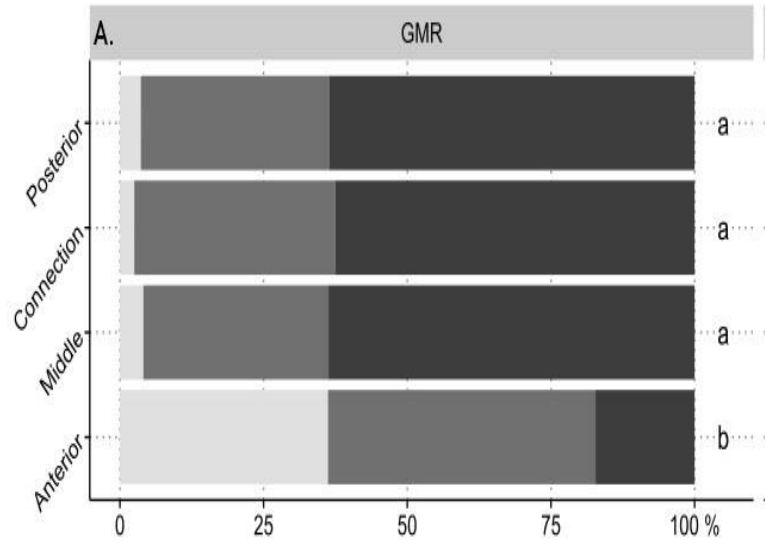

B. RRR
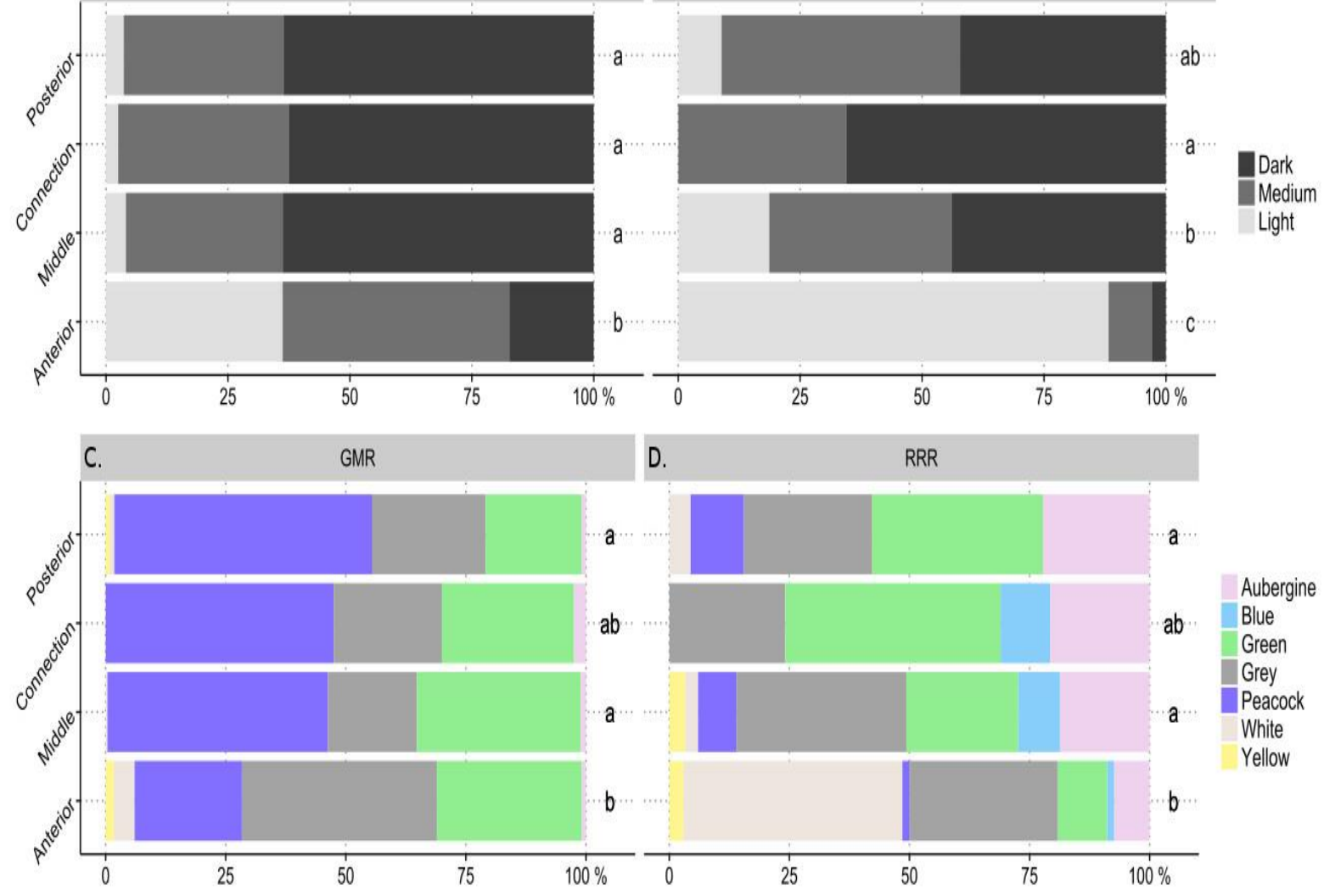

a
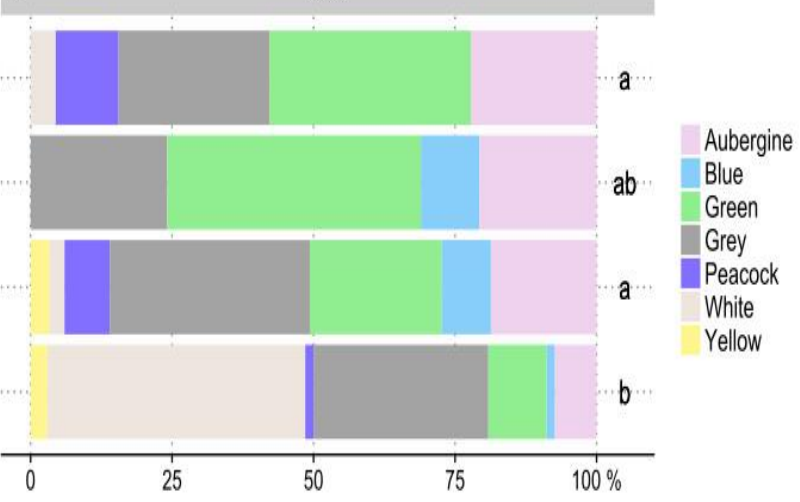
Fig. 4. Cultured pearl lustre (0, without lustre and 1 , with lustre) and surface defect ( 0 , no defects; 1, 1 to 5 defects; 2, 6 to 10 defects; and 3, up to 10 defects) in Pinctada margaritifera reared on the two commercial pearl farms on Mangareva island (GMR, parts A and C) and Raroia atoll (RRR, parts B and D). The data that were significantly different at $p<0.05$ between the mantle sections are indicated with letters.

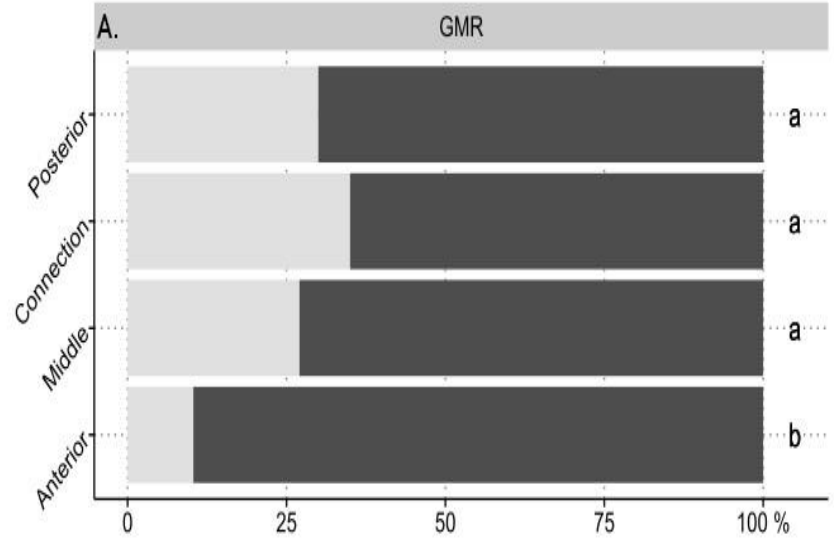

B. RRR

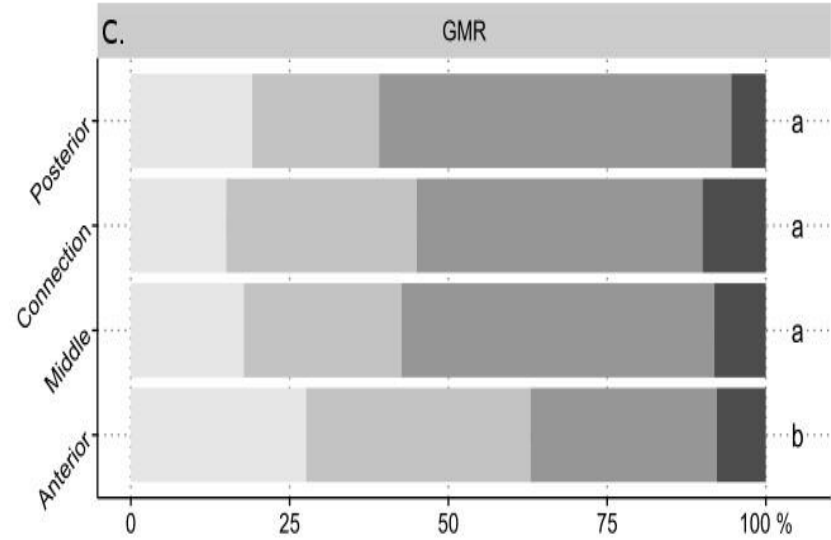

D. RRR

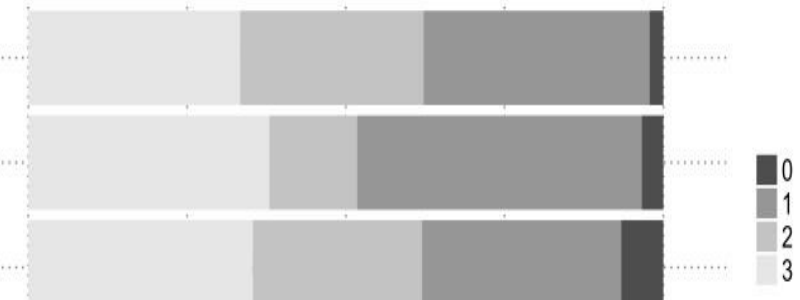


Table 1. Pinctada margaritifera used as donor for saibo production in the two commercial culture sites of Mangareva island (GMR) and Raroia atoll (RRR). Dorso-ventral measurement of the shell (shell height) from each donor oyster (in mm) and number of saibo excised from the four sections of the mantle: posterior, connection zone with the gill, middle (part usually used in commercial pearl production) and anterior, are given for the two valves, except for donor \#1 at the GMR site.

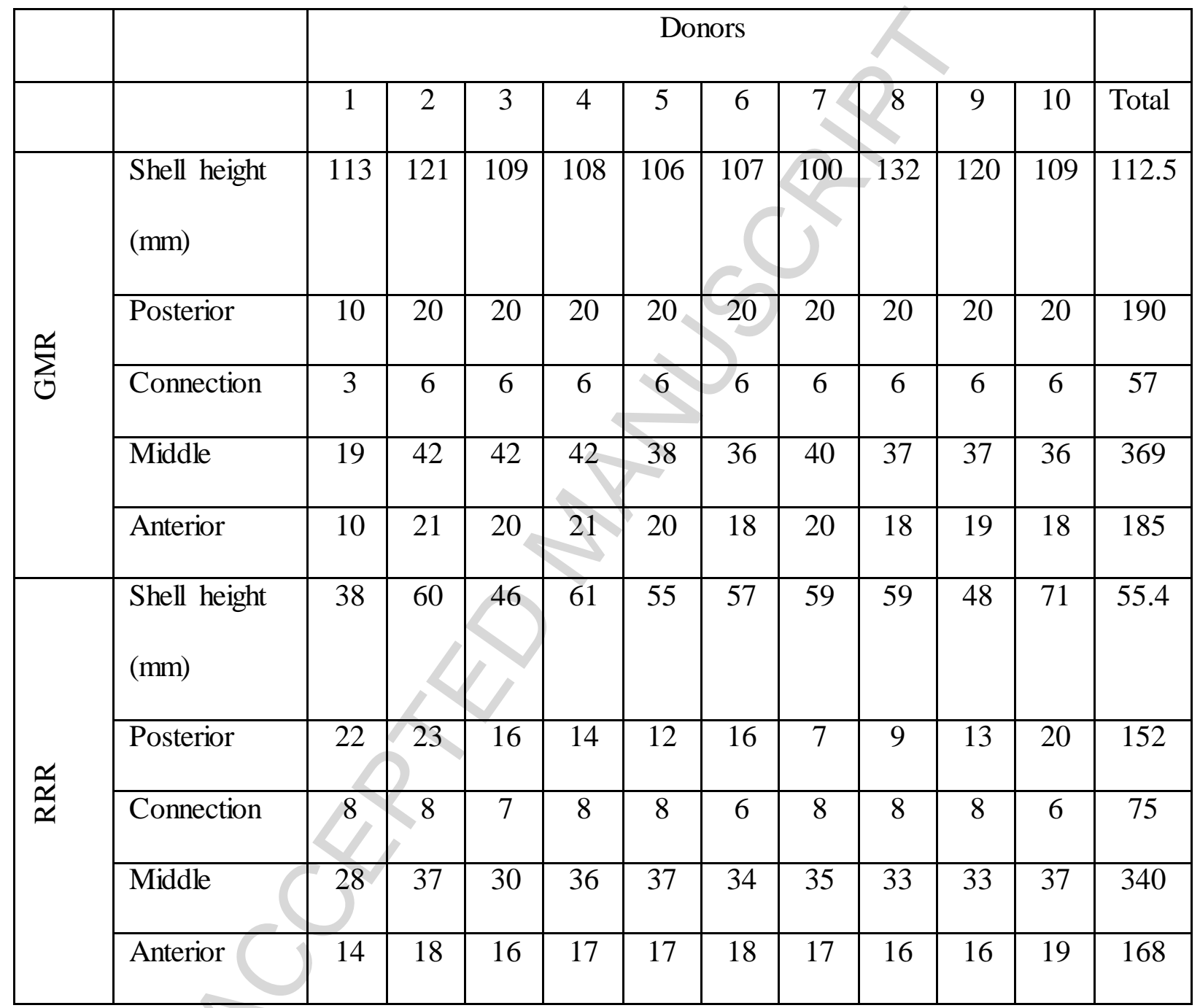


Table 2. Nucleus retention and rejection rates at 45 days post-grafting operation and oyster mortality over the culture period in Pinctada margaritifera at culture sites Mangareva island (GMR) and Raroia atoll (RRR) considered together and separately according to the four sections of the mantle used for the graft: posterior, connection zone with the gill, middle (part usually used in commercial pearl production) and anterior. The data that are significantly different at $p<0.05$ between the mantle sections are indicated with letters.

\begin{tabular}{|c|c|c|c|c|c|}
\hline & & Mantle section & Retention $(\%)(\mathrm{N})$ & Rejection $(\%)(\mathrm{N})$ & Mortality $(\%)(\mathrm{N})$ \\
\hline \multirow{4}{*}{ 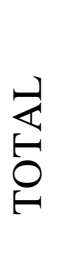 } & \multirow{4}{*}{ 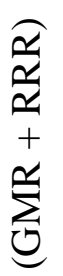 } & Posterior & $66.1(226)$ & $31.6(108)$ & $2.3(8)$ \\
\hline & & Connection & $75.8(100)$ & $23.5(31)$ & $0.7(1)$ \\
\hline & & Middle & 78.7 (558) & $19.9(141)$ & $1.4(10)$ \\
\hline & & Anterior & $77.4(260)$ & $20.8(70)$ & $1.8(6)$ \\
\hline \multirow{4}{*}{$\sum_{0}^{\alpha}$} & & Posterior & $73.7^{\mathrm{a}}(140)$ & $24.2(46)$ & $2.1(4)$ \\
\hline & & Connection & $71.9^{b}(41)$ & $26.3(15)$ & $1.8(1)$ \\
\hline & & Middle & $79.7^{b}(294)$ & $19.2(71)$ & $1.1(4)$ \\
\hline & & Anterior & $82.4^{\mathrm{b}}(138)$ & $15.5(26)$ & $2.4(4)$ \\
\hline \multirow{4}{*}{$\frac{\alpha}{\alpha, ~}$} & & Posterior & $56.6^{\mathrm{a}}(86)$ & $40.8(62)$ & $2.6(4)$ \\
\hline & & Connection & $78.7^{\mathrm{ab}}(59)$ & $21.3(16)$ & $0(0)$ \\
\hline & & Middle & $77.6^{\mathrm{b}}(264)$ & $20.6(70)$ & $1.8(6)$ \\
\hline & & Anterior & $72.6^{\mathrm{ab}}(122)$ & $26.2(44)$ & $1.2(2)$ \\
\hline
\end{tabular}

